Termite activity and decomposition are influenced by digging mammal reintroductions along an aridity gradient

Coggan, Nicole V.; Hayward, Matthew; Gibb, Heloise

\title{
Journal of Arid Environments
}

DOI:

10.1016/j.jaridenv.2016.06.005

Published: 01/10/2016

Peer reviewed version

Cyswllt i'r cyhoeddiad / Link to publication

Dyfyniad o'r fersiwn a gyhoeddwyd / Citation for published version (APA):

Coggan, N. V., Hayward, M., \& Gibb, H. (2016). Termite activity and decomposition are influenced by digging mammal reintroductions along an aridity gradient. Journal of Arid Environments, 133(October), 85-93. https://doi.org/10.1016/j.jaridenv.2016.06.005

\footnotetext{
Hawliau Cyffredinol / General rights

Copyright and moral rights for the publications made accessible in the public portal are retained by the authors and/or other copyright owners and it is a condition of accessing publications that users recognise and abide by the legal requirements associated with these rights. study or research.

downoad and print one copy of any publication from the public portal for the purpose of private

- You may not further distribute the material or use it for any profit-making activity or commercial gain

- You may freely distribute the URL identifying the publication in the public portal ?
}

Take down policy

If you believe that this document breaches copyright please contact us providing details, and we will remove access to the work immediately and investigate your claim. 
1 Termite activity and decomposition are influenced by digging mammal

2 reintroductions

3

4 Nicole V. Coggan ${ }^{1 *}$, Matthew W. Hayward ${ }^{2}$, Heloise Gibb ${ }^{1}$

5 'Department of Zoology, School of Life Sciences, La Trobe University, Melbourne, Vic., 3086,

6 Australia.

$7 \quad{ }^{2}$ Australian Wildlife Conservancy, PO Box 8070, Subiaco East, W.A., 6008, Australia.

$8{ }^{2}$ Current address: School of the Environment, Bangor University, LL572UW, United Kingdom.

9

$10 *$ Corresponding author: Email: n.coggan@latrobe.edu.au 

those species act as ecosystem engineers. Ecosystem engineers modify habitats and therefore indirectly shape plant and animal communities. However, environmental attributes, such as aridity, may influence the direct effect of engineers on habitat properties, indirectly affecting other species and the functions they perform. We used three sites where endangered digging mammals had been reintroduced to test the hypotheses that: 1 . digging mammal reintroductions affect resource consumption and abandonment by termites, and 2. locality attributes, such as aridity, influences termite interactions with reintroduced mammals. We performed two manipulative experiments to test these hypotheses. First, we tested the effects of burial resource depth on termite consumption of resources (toilet rolls). Here, resource depth was a proxy for disturbance intensity by reintroduced mammals, with shallow rolls expected to experience more disturbance. Second, we tested resource abandonment by termites in response to simulated disturbances by determining the proportion of termites remaining at disturbed resources relative to undisturbed controls over time. Both experiments were conducted at all three aridity levelssites, inside and outside exotic predator and exotic digging mammal-free reserves. We discovered that: 1 . resource consumption was $\sim 25 \%$ lower- and resource abandonment $\sim 50 \%$ higher where digging mammals were reintroduced; and 2. termite responses to reintroduced digging mammalsmammal $\underline{\text { reintroduction became less pronounced potentially -as aridity increased. We thus showed that the The }}$ near-extinction of digging mammals from much of Australia is likely to have significantly altered termite behaviour and termite-drivenactivity and decomposition, but that impacts may-potentially depend on aridity. Our work should also be considered in the context of reserve carrying capacities as it suggests, counterintuitively, that ecosystem impacts of reintroductions may be lower in resource-poor sites. 
35 Keywords: Climatic gradient, Critical weight range mammal, Decomposition, Ecosystem engineer,

36 Interactions, Termite

37 1. Introduction

38 Recent declines in biodiversity have been dramatic (e.g. Colwell et al., 2012; Dunn et al., 2009),

39 resulting in significant changes to ecosystem functioning and species assemblages (Boyer and Jetz,

40 2014; Brodie et al., 2014; Feer and Boissier, 2015; Silvey et al., 2015). Australia has the fourth- highest

41 record of species loss (IUCN 2015) and the highest rate of terrestrial mammal extinctions worldwide.

42 Thirty terrestrial mammal species have been declared extinct since European settlement (from 1788).. A

43 and a further 21 native mammals are threatened with extinction (Fleming et al., 2014; Woinarski et al.,

44 2015). Non-native predators are amongst the leading contributors to Australia's mammal extinction

45 record (Woinarski et al., 2015). Some of the greatest impacts have occurred in arid and semi-arid

46 habitats, where species of intermediate body size (35 g-5500 g, referred to as 'Critical Weight Range'

47 species), (McKenzie et al., 2007), and greater mass (up to $10 \mathrm{~kg}$, i.e. Hanna and Cardillo, 2014), have

48 been more susceptible to regional extinctions or declines. The scale of these species losses has been

49 mitigated through mammal reintroductions into fenced reserves, from which exotic predators and other

50 non-native species have been removed (e.g. Hayward and Kerley, 2009; Short and Turner, 2000).

51 Digging mammals in the critical weight range were almost completely extirpated from Australia's

52 mainland, where arid and semi-arid habitats comprise up to $70 \%$ of the total terrestrial landscape (James

Commented [MH2]: Hayward, M. W., Moseby, K. E. Read, J. L. (2014). The role of predator exclosures in the conservation of Australian fauna. In Carnivores of

Australia:: pp 363-379. Glen, A. S. , Dickman, C. R. (Eds.). Heidelberg, Melbourne, Australia: CSIRO Publishing.

53 et al., 1995). Desertification is increasing globally (Reynolds et al., 2007), ergo, the cover of arid and

Formatted: Font: Italic

55 thought to have functioned as ecosystem engineers (sensu Jones et al., 1996). Engineering impacts are 
or physical refuge (Crain and Bertness, 2006), Engineering effects However, their inputs are not

58 adversity. The magnitude of an engineer species' impacts can be context-dependent upon factors

59 including aridity or productivity (hence, resource availability), both of which are important features of

60 arid environments (Fischer and Turner, 1978; Hadley and Szarek, 1981).

61 Prior to their declines from arid habitats, burrowing bettongs (Bettongia lesueur) and greater bilbies

62 (Macrotis lagotis) were native digging mammals that made prolific contributions to soil turnover,

63 moving between one to six tonnes of soil per hectare every year (Eldridge and James, 2009). The

64 survival record of these species on the Australian mainland since 1788 is mixed. Bilbies persist in

65 isolated populations in north-western Australia and north-central Queensland (e.g. Southgate and

66 Carthew, 2006) but were lost from their central, south and south-eastern Australian range from the

671910 s to the 1930s (Pavey, 2006). In contrast, bettongs became regionally extinct from mainland

68 habitats by the 1960s (e.g. Short and Turner, 2000). Critical weight range mammal declines (especially

69 of digging mammals) represent a broad-scale loss of ecosystem function, with quantified impacts upon

70 the current structure of arid habitats and the biota within them (Fleming et al., 2014; Manning et al.,

71 2015). These include impacts upon multiple aspects of soil (Clarke et al., 2015; Eldridge et al., 2015),

72 invertebrate (Davidson and Lightfoot, 2007; Read et al., 2008; Silvey et al., 2015), and-plant

73 assemblages (e.g. Chapman, 2016; Fleming et al., 2014; Verdon et al. in review) and fire regimes (). Re-

74 establishing native mammal assemblages is anticipated to restore impacted natural ecological processes

75 (James and Eldridge, 2007; James et al., 2009; Manning et al., 2015). Digging mammals have been

76 successfully established inside sanctuaries in arid and semi-arid habitats (), but the scarcity of accurate

77 historical data needed for these types of conservation projects means that little is known of their

78 potential interactions with, nor their impacts upon pre-existing ecological assemblages (e.g. Nogués-

Commented [MH3]: Hayward, M. W., Ward-Fear, G., L'Hotellier, F., Herman, K. , Kabat, X. (2016). Could biodiversity loss have increased Australia's bushfire threat? Animal Conservation In press.

79 Bravo et al., 2016). 
80 Termites are the dominant invertebrate soil engineers and detritivores in Australian arid systems

81 (Morton et al., 2011), and are vitally important to soil health wherever they occur (de Bruyn and

82 Conacher, 1990). Prior to European colonisation, native digging mammals were likely to have been

83 important disturbance agents and predators of subterranean termites and other ground-dwelling

84 invertebrates (Gibb, 2012a; Silvey et al., 2015). Termite activity is sensitive to disturbances whichthat

85 affect the availability and suitability of their resources (e.g. Jones et al., 2003). They are therefore likely

86 to respond indirectly to soil disturbance when mammals are foraging or burrowing (Gibb, 2012a). This

87 may have cascading influences on factors such as habitat productivity, given their input into the

88 functioning of arid systems. In addition to their functional significance, termites are consumed by a

89 variety of fauna (e.g. Colli et al., 2006; Morton and James, 1988; Sheppe, 1970). They are directly

90 relevant to reintroduced digging mammals as one of their primary food sources, as a number of these

91 and other threatened critical weight range species are opportunistic dietary generalists and/or

92 insectivores (e.g. Bice and Moseby, 2008).

93 Understanding the responses of ecological assemblages to the reintroduction of regionally extinct

94 species is a developing field in ecology. New evidence indicates that critical weight range mammal

95 reintroductions (digging mammals included) have had significant influences on the community

96 assembly of arthropods by initiating trophic cascades (Silvey et al., 2015), and on soil microbes through

97 digging and defecation (Clarke et al., 2015). However, no previous studies have investigated the effects

98 of digging mammals on invertebrate activity and its implication for functions such as detritivory.

99 Understanding the impacts of mammal reintroduction on termite activity is important because of the

100 significant contribution of termites to food webs and ecological processes (i.e. Bice and Moseby, 2008;

101 Colli et al., 2006; Matthews, 1976; Morton et al., 2011; Morton and James, 1988; Sheppe, 1970),

102 particularly in arid habitats (Whitford and Kay, 1999). 
103 We used replicated comparisons of three reintroduction sanctuaries located in arid/semi-arid southern

104 Australia. Our aim was to quantify the responses of subterranean termite activity inside sanctuaries

105 where native digging mammals have been reintroduced, against controls outside the sanctuaries- where

106 native digging mammals are regionally extinct. We did this by comparing the proportion of a) resources

107 eaten by termites at different depths, and b) termites remaining at experimentally-disturbed resources

108 buried at both reintroduction and control habitats. We hypothesised that soil disturbances generated by

109 reintroduced digging mammals would reduce termite activity, resulting in lower proportions of buried

110 resources consumed, and higher proportions of resource abandonment by termites. Because aridity was

111 one of the major abiotic variables to increase across the sanctuaries, and also because engineering

112 impacts tend to be context-dependent (Crain and Bertness, 2006; McAfee et al., 2015), we also

113 considered whether different aridity levels at each sanctuary could affect the magnitude of termite

responses when digging mammals were present. We hypothesised that the effect of digging mammals on

termite foraging would be influenced by the level of aridity experienced at each sanctuary. 


\section{Methods}

\subsection{Study sites}

We compared termite responses to soil disturbance by reintroduced digging mammals at three conservation sanctuaries. These were Arid Recovery $\left(-30^{\circ} 33^{\prime} 55.38^{\prime}\right.$ 'S, $136^{\circ} 55^{\prime} 3.85^{\prime \prime} \mathrm{E}$, South

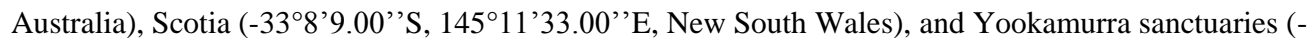
34³1'19.38’'S, 139²8’31.91’’E, South Australia) (Table 1, Fig. 1a). Scotia and Yookamurra sanctuaries were administered by the Australian Wildlife Conservancy, and Arid Recovery by BHP Billiton. Aridity varied across sanctuaries. The three sanctuaries were located along a gradient of aridity (Table 1). Temperature, precipitation, gross primary production (GPP) and the enhanced vegetation index (EVI) co varied with aridity. We used aridity indices for each site that were provided by the Australian Virtual Herbarium (Australian Virtual Herbarium 2015). We placed the aridity index value for each sanctuary relative to the others according to the United Nations Food and Agriculture Organization's (FAO) aridity index scale. preeipitation/potentialevapotranspiration (Chiew, Wang, MeConahy, James, Wright and deHoedt 2002, Tabari and Aghajanloo 2013). 'High' aridity indices eloser to 1 are less arid than 'low' indices eloser to 0 . Thus, Hyperarid zones have indices $<0.05$, Arid zones are $<0.05-60.20$, and Semi-arid

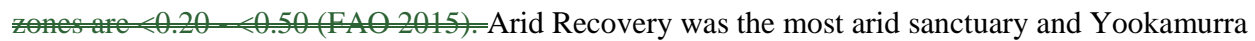
sanctuary was the least arid. Aridity indices, annual precipitation, GPP and EVI increased by an average interval of $34.11 \%$, and the mean daily maximum temperature decreased by an interval of $7.25 \%$ from Arid Recovery to Yookamurra sanctuary (Table 1). Note: Aridity indices are calculated as the annual mean ratio of precipitation/potential evapotranspiration (Chiew et al., 2002; Tabari and Aghajanloo, 2013). 'High' aridity indices closer to 1 are less arid than 'low' indices closer to 0 . Thus, Hyper-arid zones have indices $<0.05$, Arid zones are $<0.05-<0.20$, and Semi-arid zones are $<0.20-<0.50$ (FAO, 
2015). Previous research suggests that effects of (invertebrate) ecosystem engineers on vegetation communities increase with precipitation, and resource searcity promotes fidelity for termites (Lenz, Kard, Evans, Mauldin, Etheridge and Abbey 2009). We therefore hypothesised that termite responses to reintroduced mammal disturbance would increase with decreasing aridity.

The dominant vegetation class for Scotia and Yookamurra sanctuaries was remnant Mallee woodland and shrublands, with climate at Yookamurra classified as 'Mediterranean', while that at Scotia was 'Semi-arid'. Dominant ground cover at Scotia included spinifex (Triodia spp.) and chenopod species, and Westringia rigida at Yookamurra sanctuary. The dominant trees in Mallee woodlands and shrublands are Eucalyptus species, including E. dumosa and E. gracilis. Arid recovery Recovery was classified as Acacia shrubland with a 'Desert' climate. Dominant ground cover at Arid Recovery varied with season: at the time of data collection, the Poached-egg daisy (Polycalymma stuartii) and Desert Rattle-pod (Crotalaria eremaea) were abundant. Sandhill wattle (Acacia ligulata) was the dominant shrub species at Arid Recovery. Scotia and Yookamurra sanctuaries supported cryptogamic crust which bound the soil surface at those sanctuaries, whereas Arid Recovery did not.

\subsubsection{Sampling design}

All sanctuaries included large (up to $\sim \underline{86000}$ ha) enclosures free of introduced predators and protected

by predator-proof fencing. Reconstruction of native mammal assemblages commenced at Scotia

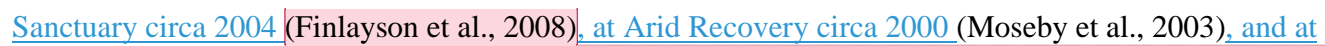

Yookamurra Sanctuary circa 1999 (Vieira et al., 2007). All sanctuaries functioned as pastoral land for

$\underline{\text { livestock (sheep and/or cattle) after European settlement and prior to their conversion into sanctuary }}$ habitats (Grolleau and Peterson, 2012). All reintroduced mammal species were considered regionally 
extinct from both reintroduction and control areas prior to the establishment of these sanctuaries (Table

\section{1). - Rabbits were present at control habitats, but had been eliminated from inside reintroduction} enclosures. The population densities of exotic species in control habitats (e.g. cats, foxes and rabbits) are routinely controlled by sanctuary management using poison baiting, trapping and shooting.

To test the effects of native digging mammals on termite foraging along the climatic gradientactivity, we performed experiments inside (reintroduced mammalian engineersdigging mammals present:

'Reintroduction') and outside the reintroduction enclosure (controls with no native mammalian engineersdigging mammals: 'Control') at each sanctuary (Fig. 1b). We paired sampling sites ( $\mathrm{n}=6)$ inside and outside the reintroduction enclosure at each sanctuary. Sites were paired to minimise the influence of spatial autocorrelation of biotic and abiotic characteristics on our response variables. Sampling sites were placed at least $150 \mathrm{~m}$ from the fence line (i.e., paired sites were at least $300 \mathrm{~m}$ apart) and, where possible, the distance between sites was $1 \mathrm{~km}$ (Fig. 1b).

2.1.3. Reintroduced mammalian-ngineer speciesmammals and presenee of reintroduced termitivores

We focused on soil disturbances caused by two reintroduced digging mammal species, burrowing bettongs, Bettongia lesueur, and greater bilbies, Macrotis lagotis (Table 1). These species were important ecosystem engineers prior to their regional extinction from the Australian mainland (James and Eldridge 2007). Bettongs and bilbies are omnivorous and include termites in their diet, although bettongs tend to consume more plant material, while bilbies are more insectivorous (Gibson, 2001; Navnith et al., 2009; Robley et al., 2001). Both species move substantial amounts of soil, within the range of 1.27-5.99 t.ha ${ }^{-1}$ per year (Eldridge and James, 2009), suggesting that termites experience markedly greater levels of soil disturbance inside sanctuaries. Numbats (Myrmecobius fasciatus) were 
184 also reintroduced at Scotia and Yookamurra sanctuaries (Vieira et al., 2007). Although this species is not

185 eonsidered an ecosystem engineer, it is exclusively termitivorous-Numbats are exclusively

186 termitivorous (Calaby, 1960), but are not digging mammals and do not function as ecosystem engineers

187 (Table 1). Interactions with numbats were not included in our hypotheses, but were acknowledged as a 188 potential influence on termite behaviour. 


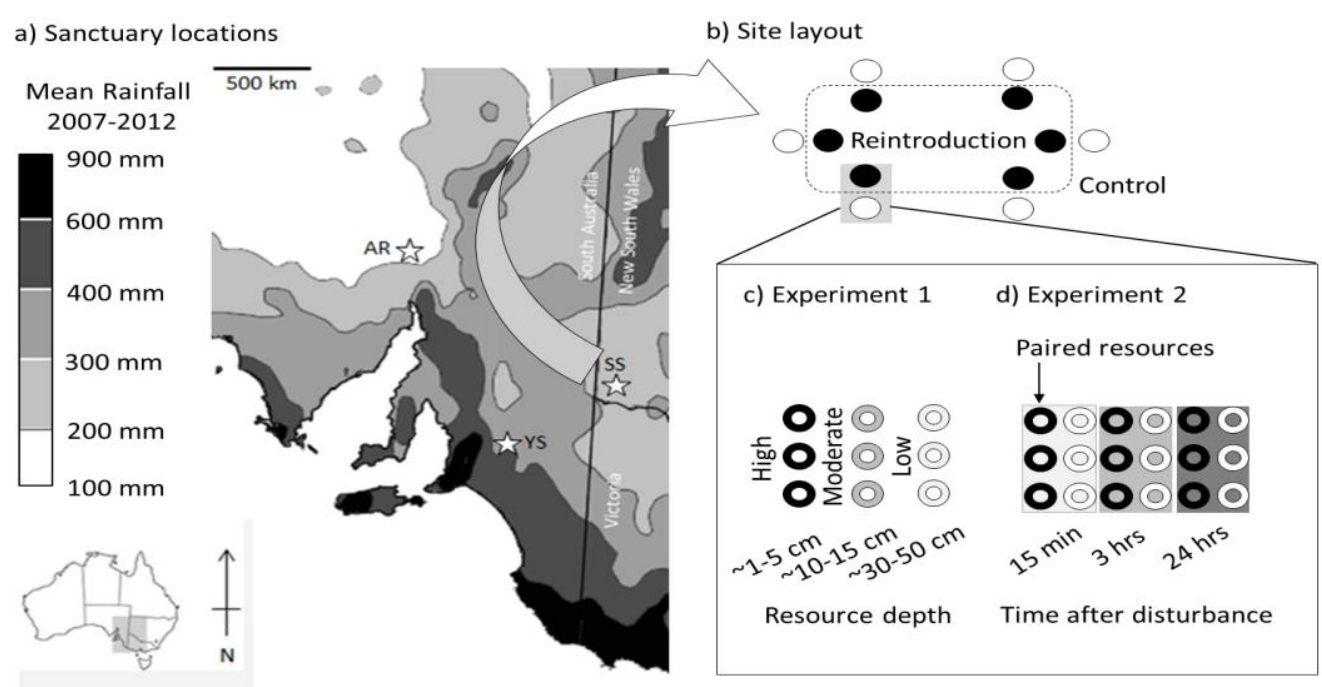

191 Fig.1 a) Map showing location of study sanctuaries relative to the precipitation gradient; b) Simplified diagram of sampling sites at each 192 sanctuary. Dashed line represents the fence dividing habitats. Comparisons of termite responses to reintroducedto engineers-digging mammals 193 were made between habitats where digging mammals were reintroduced (Reintroduction: closed circles), or regionally extinct (Control: open 194 circles); c) Resource (toilet roll) layout for Experiment 1 showing resource depth(disturbance level); d), Resource layout for Experiment 2, 195 showing 'disturbed' (black) and 'control' (white) resources and layout of blocks by observation time (shaded rectangles). AR: Arid Recovery, 196 SS: Scotia Sanctuary, YS: Yookamurra Sanctuary. 


\subsubsection{Vegetation Surveys}

We performed vegetation surveys in September 2011, prior to commencing experiments. We established twelve $5 \underline{\mathrm{m}} \times 5 \mathrm{~m}$ quadrats at each of the six paired sites in each sanctuary. In every quadrat, we estimated the percentage cover of four habitat characteristics: bare ground, ground cover, leaf litter and canopy. We also calculated the average volume of logs (lying dead wood) with a diameter $\geq 5 \mathrm{~cm}$ in every quadrat (c.f. Gibb and Cunningham, 2010). Standing stems were not measured. Log volume was estimated as the volume of a cylinder in cubic centimetres, using $\log$ length and diameter measured at the mid-point of the log. Vegetation cover was predicted to decrease with increasing aridity because precipitation_restricts resource availability (Oksanen et al., 1981). It was also expected to decrease where ecosystem engineersdigging mammals were present, because persistent soil disturbance limits opportunities of for plants to establish (e.g. Gurney et al., 2015). Climate was expected to regulate the impact of digging mammals on vegetation cover in more-arid habitats by limiting the amount of vegetation available for manipulation by engineers.

\subsection{Termite responses}

\subsubsection{Experiment 1: Resource consumption-under increasing soil-disturbance intensity.}

We performed an experiment using resources buried at three depths to test the effect of soil disturbance by reintroduced ecosystem engineersdigging mammals on termite foraging across the climatic gradientactivity. We used resource depth as a surrogate for disturbance intensity. A longitudinal study of soil disturbance indicated that the average foraging pit constructed by bilbies and bettongs is 10-20 cm (Travers, 2013). We therefore expected that resource consumption by termites would be affected most by reintroduced ecosystem engineerssoil 
219 disturbance at depths less than $10 \mathrm{~cm}$, moderately affected at depths less than $20 \mathrm{~cm}$ and not

220 affected at depths greater than $20 \mathrm{~cm}$.

221 In February 2012, we buried nine unscented toilet paper rolls ('resources') in a $3 \underline{\mathrm{m}} \times 3 \underline{\mathrm{m}}$ grid at 222 each of the 6 paired sampling sites in each sanctuary (Fig.1a-c). We used toilet rolls as resources because they were attractive to common soil and wood-feeding termite genera (Coptotermes, and Heterotermes), whose ranges intersected all of our study sites (French and Robinson, 1981;

225 Watson and Abbey, 1993). A row of three resources was buried at each of the three depths,

226 where depth was a surrogate for disturbance. Treatments were: 1) intensely disturbed resources

227 ('High disturbance'), 1-5 cm below ground (these represented the zone of highest resource exposure to soil disturbance); moderately disturbed resources ('Moderate disturbance'), 10-15 $\mathrm{cm}$ below ground (these were close to the average maximum depth of engineer diggings); and least disturbed resources ('Low disturbance'), 30-50 cm below ground, where the majority of

231 engineer disturbancediggings should be avoided (Fig. 1c). In August/September 2012, we unearthed the resources and visually estimated the proportion of each resource that termites had consumed: $0 \%$ consumption indicated that the resource remained intact, and $100 \%$ consumption indicated that the resource was completely consumed.

\subsubsection{Experiment 2. Effect of intense soil disturbance on resource abandonment by} termites $\underline{\text { Resource abandonment. }}$

237 We hypothesised that disturbance would increase the rate ofaffect resource abandonment by

238 termites. Disturbance caused by reintroduced digging mammals was expected to expose termite

239 foragers to threats such as desiccation or to attack by termite predators, which also include the

240 reintroduced mammals themselves (Table 1). We tested the effects of disturbance on termites by 
241 comparing termite abundances on experimentally disturbed resources with those on controls

242 (undisturbed resources) over 24 hours (Fig. 1d).

243 In February 2012, we buried nine resources in pairs within a $3 \underline{\mathrm{m}} \times 3 \underline{\mathrm{m}}$ grid at each of the six

244 paired sites at each sanctuary (Fig. 1d). Resources were buried approximately $5 \mathrm{~cm}$ below ground, within the range of highest soil disturbance intensity by reintroduced mammals (see

Experiment 1). Resource pairs were separated by 5-10 cm and rows were $1-2 \mathrm{~m}$ apart (Fig. 1d). Termites were allowed to colonize resources until August/September 2012, when we applied our disturbance treatment. For each pair, we disturbed one resource by unearthing it and leaving it unburied in its hole, and one resource, the 'control', undisturbed. The purpose of the control resource was to estimate the number of termites using undisturbed resources. We disturbed termite resources between $0900 \mathrm{~h}-1000 \mathrm{~h}$ to standardize temporal conditions at our sampling sites. Resource abandonment in response to our disturbance was measured by comparing the number of termites in the 'disturbed' and 'control' resources. We examined each row separately at 15 minutes, 3 hours and 24 hours after our initial disturbance treatment. Each replicate resource was examined only once, i.e. termites inside resources from row 1 were collected and counted after 15 minutes, from row 2 after 3 hours, and from row 3 after 24 hours following resource disturbance. For each pair, we counted the number of termites remaining in the disturbed resource and its control. For tests of the effect of digging mammals and climate on resource abandonment, we standardised each response by the total number of termites at the pair (ControlDisturbed)/(Control+Disturbed). We identified termite species whenever soldiers were found (soldiers were required for identification). We also noted predation by ants on termites, i.e., ants

262 carrying termites away (Fig. 1d), at the disturbed resources. Finally, we calculated the proportion of disturbed resources that were attended by ants and photographed ants for later identification to genus. 


\subsection{Data Analysis}

266

We used a generalized linear model (GLM) and Tukey’s post-hoc tests with Bonferroni

267 corrections to test the effect of ecosystem engineerdigging mammal reintroduction on vegetation cover. We also used GLMs to compare termite and ant responses to soil disturbance in habitats

270 termite activity in both experiments. In experiment 2 , note that we used the binomial distribution

271 for ant data, as these described either the presence or absence of ants. Tukey's post-hoc tests with

272 Bonferroni corrections were used to determine differences among interacting factors. All

273 analyses were conducted using $\mathrm{R}(\mathrm{R}$ Core Team, 2015).
Commented [MH10]: Do you need to mention the link function?

Commented [MH11]: Do you need to mention the models used and cite the coders for them? 
275 3. Results

276 3.1. General

277 3.1.1.Habitat Surveys

278 Habitat cover differed among sanctuaries, with habitat structure decreasing with aridityfrom

279 Yookamurra to Arid Recovery, and Scotia intermediate between the two (Table 2). Yookamurra

280 had the greatest volume of $\operatorname{logs}:-\mathrm{m}^{-2}$, the densest canopy, and the least bare ground (Table 2 Post-

281 hoc). At the opposite end of the scale, Arid Recovery consistently had the lowest percentage

282 cover of all recorded habitat types, and had very few logs with a diameter $>5 \mathrm{~cm}$, with wood

283 resources concentrated at patches of dead Sandhill wattle (Table 2, Post-hoc). Scotia was similar

284 to Arid Recovery in terms of bare ground and canopy cover, but closer to Yookamurra in terms

285 of ground cover. Leaf litter and logs at Scotia were intermediate between Arid Recovery and

286 Yookamurra sanctuaries (Table 2).

287 
Species of Heterotermes comprised the overwhelming majority of termites collected in both experiments; Coptotermes were collected in very small numbers. Trench surveys from a related

experiment estimated the average density of Heterotermes and of Coptotermes as follows:

Heterotermes: Arid Recovery (AR) $87 \pm 22$ termites.m ${ }^{-2}$, Scotia (SS) $137 \pm 21$ termites. m $^{-2}$,

Yookamurra (YS) $112 \pm 19$ termites. $\mathrm{m}^{-2}$. Coptotermes: AR $63 \pm 42$ termites.m ${ }^{-2}$, SS $120 \pm 47$

termites. $\mathrm{m}^{-2}$, YS $36 \pm 34$ termites. $\mathrm{m}^{-2}$.

3.2. Experiment 1: Resource eөnsumption-under increasing soil-disturbance intensity and increasing aridityconsumption.

Average resource decomposition by termites was $53.25-\underline{3} \pm 2.09-1 \%$ upon-observation-after 6 months' burial. We found a significant three-way interaction between the presence of digging mammals, depth and aridity sanctuary location (Table 3). There was no difference in resource consumption with resource depth (disturbance intensity) where engineers digging mammals were excluded (Fig. 3, post-hoc: P>0.05). However, when reintroduced engineers-digging mammals were present, resource consumption at the low disturbance treatment $(1-5 \mathrm{~cm})$ was greater than at the high disturbance treatment $(30-50 \mathrm{~cm})$ (Fig. 3).

At $1-5 \mathrm{~cm}$ depths, the effect of reintroductions of digging mammals on resource consumption by termites (i.e., the difference inside and outside the sanctuary) increased with decreasing aridity (Fig. 3a-c, post-hoc: $\mathrm{P}<0.0001)$. 


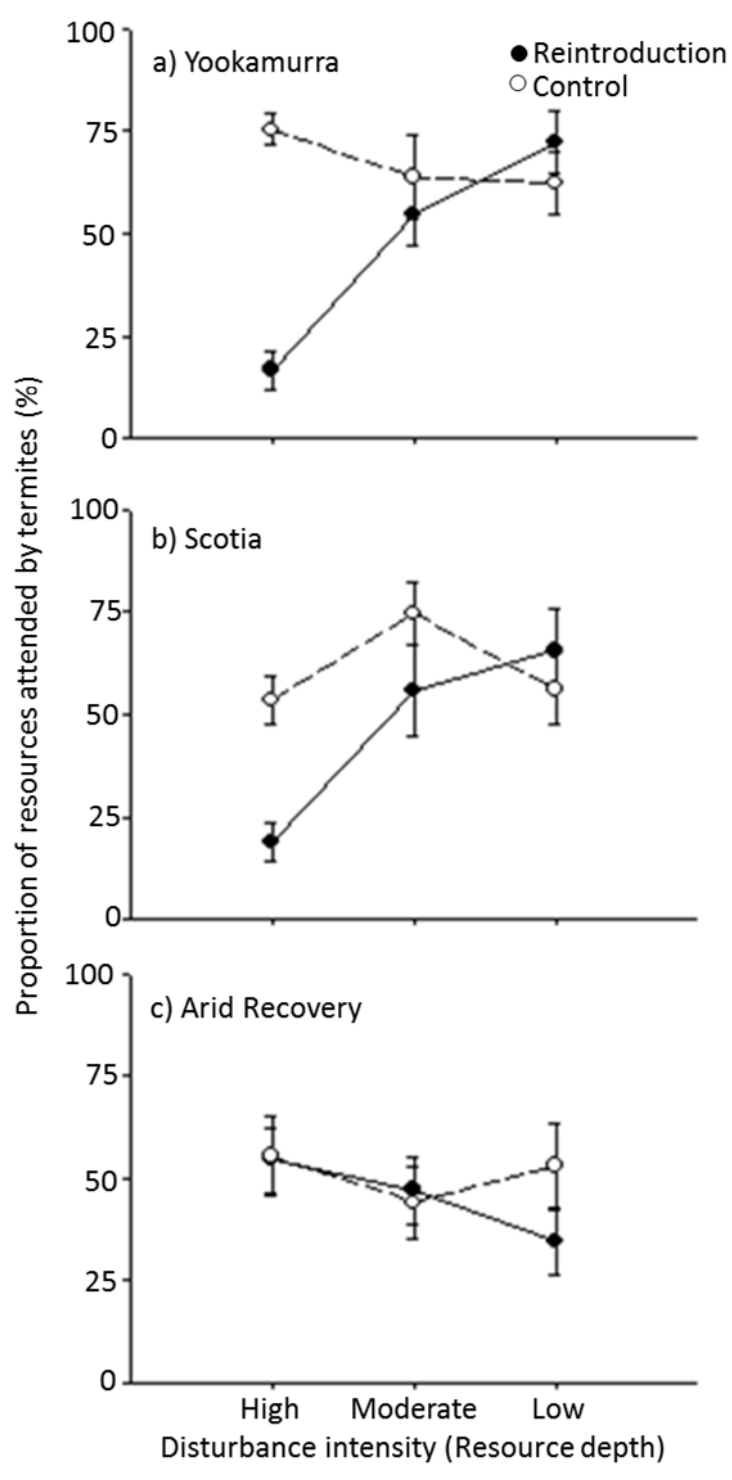

309 Fig. 3: Mean \pm SE proportion of resources consumed by termites exposed to increasing levels of 310 soil disturbance in Experiment I. Graphs for each sanctuary are presented in order of aridity,

311 from least arid (a, Yookamurra), to most arid (c, Arid Recovery). 
314 3.3. Experiment 2: Resource abandonment-following soil-disturbance.

315 Soil disturbanceExperimentally-disturbing buried resources significantly increased rates of

316 resource abandonment by termites over time, and rates of $\underline{\text { Resource abandonment were was }}$

317 higher when digging mammals were present (Table 4, Termites; Fig. 4a-c). Aridity The location

318 of sanctuaries did not affect resource abandonment by termites (Table 4, Termites). The number

319 of termites remaining on resources declined with time since disturbance at Yookamurra and

320 Scotia Sanctuaries (Fig. 4a-b) (effect size contrast: 15 mins $>3$ hrs $>24$ hrs $(\mathrm{p}<0.05)$. The

321 number of termites remaining after disturbance at Arid Recovery fluctuated between the $3 \mathrm{hr}$ and

$32224 \mathrm{hr}$ observation times (Fig. 4c).

323 Ants were observed carrying termites away from disturbed resources and we used ant attendance

324 at resources as a surrogate for ant predation on termites. Time since disturbance, engineer status

325 and aridity sanctuary interacted to affect ant attendance at resources. Control and reintroduction

326 sites differed after 3 hrs and 24 hrs, but only at Scotia and Yookamurra sanctuaries. At 24 hrs,

327 the effect size (difference between control and reintroduction) decreased with increasing

328 aridityfrom Yookamurra sanctuary to Arid Recovery, which was the most arid sanctuary (Figs.

329 4d-f). Iridomyrmex purpureus was the most frequently observed ant species preying on termites. 

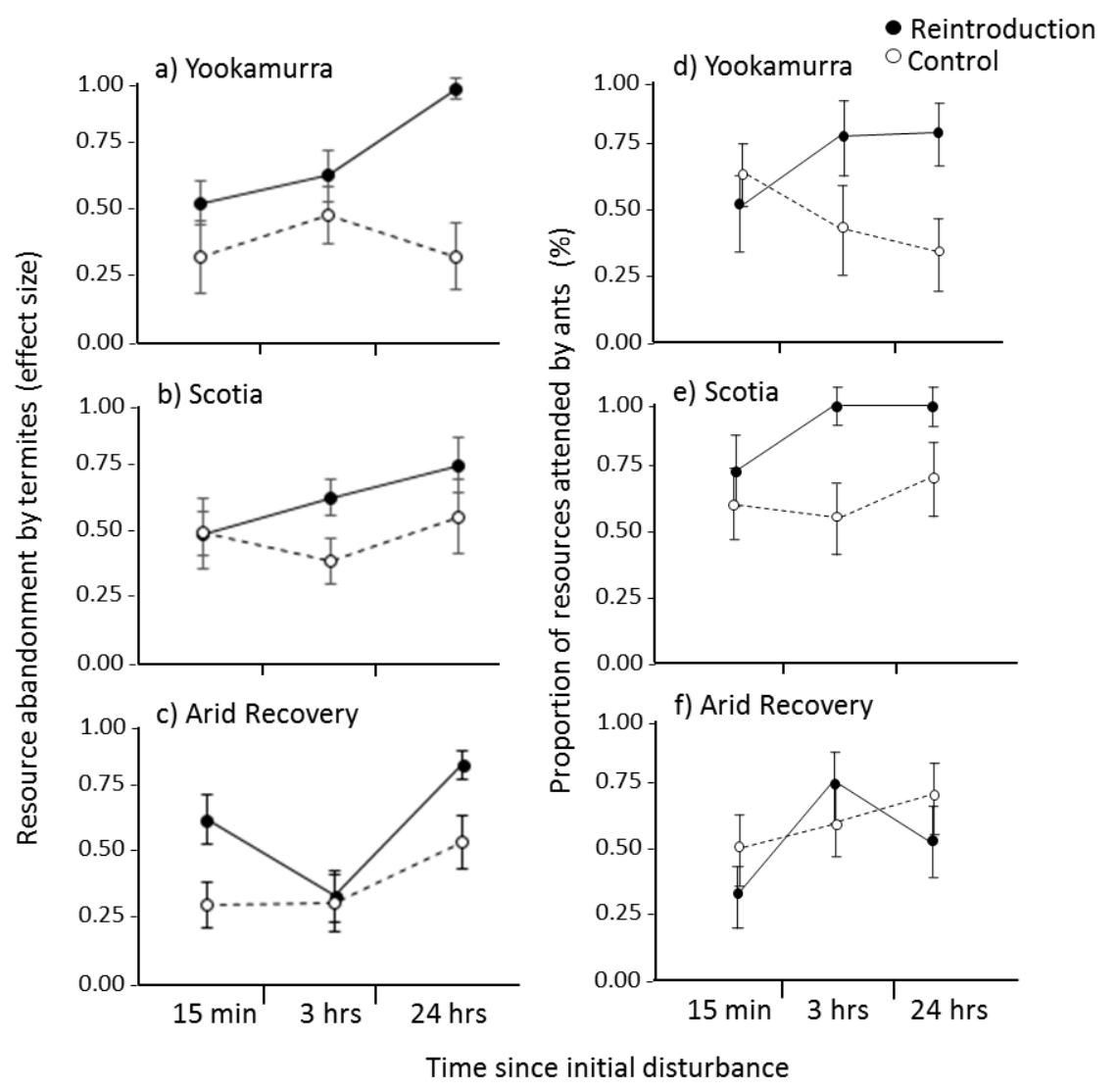

332

Time since initial disturbance

333 Fig. 4, Mean \pm SE resource abandonment by termites (a-c) and termite predation by ants (d-f)

334 following soil disturbance. Graphs are presented in order of the aridity at each sanctuary, from

335 least arid (a \& d, Yookamurra), to most arid (c \& f, Arid Recovery). 


\section{Discussion}

Previous studies have shown that digging mammals alter invertebrate community assemblages through ecosystem engineering (Davidson and Lightfoot, 2007; Read et al., 2008). Their effects are associated with changes to habitat structure and/or complexity, such that assemblages that take advantage of engineered habitats (for example, burrows), are distinct from surrounding habitats that have not been engineered (e.g. Bravo et al., 2009). Invertebrate, and invertebrate assemblages may be further altered through predation by reintroduced digging mammals and resulting trophic cascades (Silvey et al., 2015). This is the first study to-We show that interactions with digging mammalsreintroduced digging mammals -also negatively affect ecosystem functions performed by invertebratestermite activity, an impact that has not been previously examined in the context of reintroducing regionally-extinct species. Termite activity was approximately $25 \%$ lower and resource abandonment about $50 \%$ higher than controls when $\underline{\text { digging mammals were reintroduced. We also observed a decrease in the effect magnitude of }}$ $\underline{\text { termite responses from Yookamurra sanctuary to Arid Recovery. These may be attributed to }}$ greater aridity levels and resource availability at Arid Recovery versus the other sanctuaries, $\underline{\text { which we will discuss. }}$

Digging mammals such as the greater bilby and burrowing bettong move a significant volume of soil each year (Eldridge and James, 2009). Termites were expected to alter their resource consumption to avoid soil disturbances (Brown et al., 1999), resulting in a decreaseddecreases rate of termite activity that could ultimately influence decomposition, one of their primary ecological functions. - Data from Experiment I supported this prediction: shallow resources that were exposed to the most intense levels of soil disturbance (those at shallow depths)-were consumed less by termites when engineers-digging mammals were present. In contrast, resource consumption was independent of resource disturbance intensity (resource depth)disturbance 
363 when engineers digging mammals were absent. This shift in resource consumption suggests that

364 termites were either actively avoiding, or were less successful at consuming resources-where soif

372 We showed a clear (aridity dependent) diminution in termite activity in the upper layers of soil

373 in the presence of digging mammals, although this was greater at Yookamurra and Scotia sanctuaries. While previous studies have focussed on the biodiversity impacts of the loss of

disturbance was greater when digging mammals were present. Termite populations decline following habitat disturbances that disrupt their food supplies, for example, shortly following fires, or when habitats shift towards lower plant diversity (e.g. in plantations) (Dosso et al., 2013). It is therefore possible that this change in function resulted from a change in population density of termites. However, preliminary data suggest that this is not the case (Coggan \& Gibb in prep), so changes in resource consumption may be the result of changes in termite behaviour, considered in Experiment 2. ecosystem engineers (Romero et al., 2015), few studies have examined the ecological cascades or functional changes resulting from changes in behaviour or population densities of species with which ecosystem engineers such as digging mammals interact. - Termites are the dominant detritivores in arid Australia (Morton et al. 2011), and the change in activity resulting in lower levels of resource consumption in the presence of digging mammals may translate into decreased decomposition (in the manner that functioning decreases along disturbance intensity gradients, i.e. McDonnell et al., 1997). Any such changes in termite-driven decomposition may significantly alter soil nutrient cycling, with potential cascades through to habitat productivity. Our study suggests that reintroduction of digging mammals that function as ecosystem engineers might lead to decreases in decomposition rates, at least in the upper soil layer where foraging disturbance is most intense. Although it is possible that termite-driven decomposition has increased following the loss of digging mammals from the Australian arid zone, the outcome of
Commented [MH14]: I'd use an easier word - simplify your writing so people will understand your message (esp those who don't have English as their first language, but still write papers and so may cite your work).

Field Code Changed Field Code Changed 
reintroductions for nutrient cycling are likely to be complex, with further studies required to better elucidate the full complexity of interactions.

389 Reintroductions of digging mammals were associated with increased-greater resource abandonment by termites, suggesting a behavioural response to disturbance might be the mechanism determining reduced resource consumption. Several species of native mammals (digging and non-digging) reintroduced to our study sites prey on invertebrates, which may result in cascading effects on invertebrate assemblages. For example, Silvey et al. (2015) documented mesopredator release in arachnid assemblages, where mammal predation reduced the abundance of the dominant scorpion species, triggering a trophic cascade in scorpion and ground-dwelling spider communities (Silvey et al., 2015). Previous studies have also reported that some species display behavioural responses to predators that minimise predation risk, but which also reduce foraging success (i.e. the 'landscape of fear', Lima and Dill, 1990), although extreme hunger will reverse alter the priorities of risk in order to avoid certain death by starvation over uncertain death by potential predators (Lima, 1998). Differences in resource abandonment rates-between control and reintroduction sites for similarly disturbed resources-suggest that termites may experience a landscape of fear effect in the presence of digging mammals. Laboratory experiments show that resource abandonment by termites depends on the level of danger that termites perceive (Gautam and Henderson, 2012). Increased rates ofresource abandonment in reintroductions might therefore be a result of perceived threats of predation by reintroduced native mammals (including digging species) digging mammals or other organisms affected by the reintroductions.

Disturbed resources were attended by ants within minutes of exposure when engineers were presentexposure, and their attendance was greater at disturbed resources when digging mammals

\section{Field Code Changed}

Field Code Changed

Commented [MH15]: And we found this here: Hayward, M. W., Ortmann, S. , Kowalczyk, R. (2015). Risk perception by endangered European bison Bison bonasus is context (condition) dependent. Landscape Ecol 30, 2079-2093.

Field Code Changed

Field Code Changed

Field Code Changed

Field Code Changed 
411 habitat disturbance alters invertebrate assemblages, favouring aggressive ant genera such as

412 Iridomyrmex (Gibb and Hochuli, 2003). Ant attendance at resources was greater in

413 reintroduction than control sites, suggesting ant predation rates on termites may be higher when

414 termites are exposed to disturbance when digging mammals are present. Declines in numbers of

415 termites at resources in the presence of digging mammals may therefore have resulted from both

416 the direct process of predation by ants or digging mammals, and the indirect process of predation

417 or disturbance avoidance.

418 Changes in termite activity in the presence of digging mammals tended to be greatest at

Yookamurra sanctuary, moderate at Scotia sanctuary, and not different from controls at Arid

420 Recovery. We suggest that the differences in effect magnitude were associated with habitat

421 (resource) availability, which differed at each sanctuary, for example, where vegetation resources covered more area at Yookamurra and Scotia than at Arid Recovery, which had more bare ground. The historical use of sanctuary land to run non-native livestock (cattle and/or sheep)

before they were re-purposed for conservation is one factor that could strongly affect habitat

availability. The presence of livestock in arid lands has lasting impacts on habitat structure.

These include changes in the proportions of bare ground and low vegetation to taller plant types

(e.g. shrubs), and the long-term impact on habitat cover can be observed when livestock is

absent as those taller plant classes return (e.g. Eldridge et al., 2011). Persistent soil disturbance in

addition to different mammal densities (where digging is an engineering function) also limits

opportunities for plants to establish (e.g. Gurney et al., 2015; McAfee et al., 2015). Both of these

factors are likely to contribute to the habitat cover observed at each sanctuary, in addition to

$\underline{\text { aridity, which was lower at Yookamurra and Scotia than at Arid Recovery. The influence of }}$

$\underline{\text { rainfall (aridity) over productivity is one of the defining aspects of arid habitats (Fischer and }}$

Turner, 1978; Hadley and Szarek, 1981; Rodríguez-Castañeda, 2013), with less vegetation
Field Code Changed

Field Code Changed

\section{Field Code Changed}

Field Code Changed

Field Code Changed

Field Code Changed

Field Code Changed

Field Code Changed

Field Code Changed

Field Code Changed

Field Code Changed 
expected in more arid habitats (Oksanen et al., 1981). Results from the first experiment indicated that avoiding disturbance was important for termites in less-arid sanctuaries, where resources

such as wood and leaf litter were more available. The cost of leaving a resource would be higher in more arid environments where fewer alternative resources were available. Resource scarcity, such as the low wood availability observed at Arid Recovery, might thus encourage higher fidelity to resources by termites. Different responses to resource-use based on the relative value

of scarce resources have previously been observed in termites, for example, Reticulitermes

flavipes consumed resources more slowly when resources were scarce (Lenz et al., 2009).

Productivity might also affect ant predation: more productive environments might support larger densities of ants, such that the chance of discovery of termite prey would be higher. Further investigation is required to test this hypothesis.

\section{Conclusions}

We observed clear effects of digging mammal reintroductions on termite activity, which were $\underline{\text { significantly reduced when those mammals were present. An additional pattern suggested that }}$ termite responses were influenced by resource availability, which could be affected by factors such as aridity and land-use history. Our explicit test of termite responses to soil disturbance by mammals adds to our growing empirical understanding of interactions between digging mammals and ground-dwelling invertebrates. Our results suggest that Australian arid ecosystems may have been substantially different prior to the ecological extinction of digging mammalian engineers. They also highlight the complexity of species interactions, with mammal disturbance also altering termite interactions with invertebrate predators (ants). Termites are important food resources for other species, key detritivores in the decomposition process, and ecosystem engineers that affect soil processes and vegetation patterns, especially in arid environments (Evans et al., 2011; Gibb, 2012b; Mora et al., 2005). The lessening of termite activity when
Field Code Changed

Field Code Changed

\section{Field Code Changed}

Field Code Changed 
digging mammals were present is an interesting point to consider, as it could indicate a shift in

$\underline{\text { the location of resource decomposition into deeper, less-disturbed soil. The relevance of }}$

$\underline{\text { sanctuary-specific background factors including aridity land-use history (among others) still }}$

require empirical exploration beyond what we uncovered using only three sites. The trends that

we observed agree with the context-dependency of engineering impacts (McAfee et al., 2015),

but run counterpoint to theories that engineering ought to benefit interacting organisms with

increasing environmental adversity (Crain and Bertness, 2006). - This novel finding suggests that

it may be more difficult to generalise about the effects of digging mammals on ecosystems than anticipated, and that higher carrying capacities of less arid environments may also be linked with greater ecosystem sensitivity. This study adds to the small, but growing, volume of research showing that the decline of digging mammals has had broad-reaching effects on invertebrates (e.g. Davidson and Lightfoot, 2007; Silvey et al., 2015), and makes substantial advances in our understanding of impacts on invertebrate-driven decomposition, a critical ecosystem function.

\section{Acknowledgements}

We thank D. Eldridge, M. Van de Wetering, S. Avitabile, J. Grubb, S. Watson and anonymous reviewers for their valuable assistance in preparing this manuscript. We are grateful to the volunteers who assisted with fieldwork and also to the ANZ Holsworth Wildlife Research Endowment, Australian Wildlife Conservancy, Arid Recovery and the Australia and Pacific Science Foundation for their financial and logistical support. NVC was supported by an Australian Postgraduate Award, HG was supported by a Future Fellowship (FT130100821).

\subsection{Conflict of interest disclaimer}

We confirm no conflicts of interest on behalf of the authors associated with this manuscript.
Field Code Changed

Field Code Changed

Field Code Changed

Field Code Changed

Field Code Changed

Field Code Changed

Field Code Changed 


\section{References}

1. Bice, J., Moseby, K., 2008. Diets of the re-introduced greater bilby (Macrotis lagotis) and burrowing bettong (Bettongia lesueur) in the Arid Recovery Reserve, Northern South Australia. Australian Mammalogy 30, 1-12.

2. Boyer, A.G., Jetz, W., 2014. Extinctions and the loss of ecological function in island bird communities. Global Ecology and Biogeography 23, 679-688.

3. Bravo, L.G., Belliure, J., Rebollo, S., 2009. European rabbits as ecosystem engineers: warrens increase lizard density and diversity. Biodiversity and Conservation 18, 869-885.

4. Brodie, J.F., Aslan, C.E., Rogers, H.S., Redford, K.H., Maron, J.L., Bronstein, J.L., Groves, C.R., 2014. Secondary extinctions of biodiversity. Trends in Ecology and Evolution 29, 664-672.

5. Brown, J.S., Laundré, J.W., Gurung, M., 1999. The ecology of fear: optimal foraging, game theory, and trophic interactions. Journal of Mammalogy 80, 385-399.

6. Calaby, J., 1960. Observations on the banded ant-eater Myrmecobius fasciatus Waterhouse (Marsupialia), with particular reference to its food habits. Proceedings of the Zoological Society of London 135, 183-207.

7. Chapman, T.F., 2016. Comparison of soils and plants on the active and relic parts of a recolonised burrowing bettong (Bettongia lesueur) warren. Pacific Conservation Biology 21, 298306.

8. Chiew, F., Wang, Q., McConachy, F., James, R., Wright, W., deHoedt, G., 2002. Evapotranspiration Maps for Australia [online]. Institution of Engineers, Barton, A.C.T.

9. Clarke, L.J., Weyrich, L.S., Cooper, A., 2015. Reintroduction of locally extinct vertebrates impacts arid soil fungal communities. Molecular Ecology.

10. Colli, G.R., Constantino, R., Costa, G.C., 2006. Lizards and termites revisited. Austral Ecology 31, 417-424.

11. Colwell, R.K., Dunn, R.R., Harris, N.C., 2012. Coextinction and persistence of dependent species in a changing world. Annual Review of Ecology, Evolution, and Systematics 43, 183-203.

12. Crain, C.M., Bertness, M.D., 2006. Ecosystem engineering across environmental gradients: implications for conservation and management. Bioscience 56, 211-218.

13. Davidson, A.D., Lightfoot, D.C., 2007. Interactive effects of keystone rodents on the structure of desert grassland arthropod communities. Ecography 30, 515-525.

14. de Bruyn, L., Conacher, A., 1990. The role of termites and ants in soil modification - a review. Soil Research 28, 55-93.

15. Dosso, K., Deligne, J., Yéo, K., Konaté, S., Linsenmair, K., 2013. Changes in the termite assemblage across a sequence of land-use systems in the rural area around Lamto Reserve in central Côte d'Ivoire. Journal of Insect Conservation 17, 1047-1057.

16. Dunn, R.R., Harris, N.C., Colwell, R.K., Koh, L.P., Sodhi, N.S., 2009. The sixth mass coextinction: are most endangered species parasites and mutualists? Proceedings of the Royal Society of London B: Biological Sciences 276, 3037-3045.

17. Eldridge, D.J., Bowker, M.A., Maestre, F.T., Roger, E., Reynolds, J.F., Whitford, W.G., 2011. Impacts of shrub encroachment on ecosystem structure and functioning: towards a global synthesis. Ecology Letters 14, 709-722.

18. Eldridge, D.J., James, A.I., 2009. Soil-disturbance by native animals plays a critical role in maintaining healthy Australian landscapes. Ecological Management \& Restoration 10, S27-S34.

19. Eldridge, D.J., Woodhouse, J.N., Curlevski, N.J.A., Hayward, M., Brown, M.V., Neilan, B.A., 2015. Soil-foraging animals alter the composition and co-occurrence of microbial communities in a desert shrubland. ISME J 9, 2671-2681. 
20. Evans, T.A., Dawes, T.Z., Ward, P.R., Lo, N., 2011. Ants and termites increase crop yield in a dry climate. Nature Communications 2, 262.

21. FAO, 2015. FAO GEONETWORK, Food and Agriculture Organization of the United Nations. FAO, Rome, Italy.

22. Feer, F., Boissier, O., 2015. Variations in dung beetle assemblages across a gradient of hunting in a tropical forest. Ecological Indicators 57, 164-170.

23. Finlayson, G.R., Vieira, E.M., Priddel, D., Wheeler, R., Bentley, J., Dickman, C.R., 2008. Multi-scale patterns of habitat use by re-introduced mammals: A case study using medium-sized marsupials. Biological Conservation 141, 320-331.

24. Fischer, R., Turner, N.C., 1978. Plant productivity in the arid and semiarid zones. Annual Review of Plant Physiology 29, 277-317.

25. Fleming, P.A., Anderson, H., Prendergast, A.S., Bretz, M.R., Valentine, L.E., Hardy, G.E., 2014. Is the loss of Australian digging mammals contributing to a deterioration in ecosystem function? Mammal Review 44, 94-108.

26. French, J., Robinson, P., 1981. Baits for aggregating large numbers of subterranean termites. Australian Journal of Entomology 20, 75-76.

27. Gautam, B.K., Henderson, G., 2012. Escape behavior of the Formosan subterranean termite (Isoptera: Rhinotermitidae) in response to disturbance. Journal of Insect Behavior 25, 70-79.

28. Gibb, H., 2012a. How might terrestrial arthropod assemblages have changed after the dramatic decline of critical weight range (CWR) mammals in Australia? Using reintroductions at Scotia Sanctuary as a model for pre-European ecosystems, Proceedings of the Linnean Society of New South Wales.

29. Gibb, H., 2012b. How might terrestrial arthropod assemblages have changed after the dramatic decline of critical weight range (CWR) mammals in Australia? Using reintroductions at Scotia Sanctuary as a model for pre-European ecosystems. Proceedings of the Linnean Society of New South Wales 134.

30. Gibb, H., Cunningham, S., 2010. Revegetation of farmland restores function and composition of epigaeic beetle assemblages. Biological Conservation 143, 677-687.

31. Gibb, H., Hochuli, D.F., 2003. Colonisation by a dominant ant facilitated by anthropogenic disturbance: effects on ant assemblage composition, biomass and resource use. Oikos 103, 469478.

32. Gibson, L.A., 2001. Seasonal changes in the diet, food availability and food preference of the greater bilby (Macrotis lagotis) in south-western Queensland. Wildlife Research 28, 121-134.

33. Grolleau, G., Peterson, D., 2012. Biodiversity conservation through private initiative: the case of Earth Sanctuaries Ltd. European Journal of Law and Economics 40, 293-312.

34. Gurney, C.M., Prugh, L.R., Brashares, J.S., 2015. Restoration of native plants is reduced by rodent-caused soil disturbance and seed removal. Rangeland Ecology \& Management 68, 359366.

35. Hadley, N.F., Szarek, S.R., 1981. Productivity of Desert Ecosystems. BioScience 31, 747-753.

36. Hanna, E., Cardillo, M., 2014. Predation selectively culls medium-sized species from island mammal faunas. Biology Letters 10, 20131066.

37. Hayward, M.W., Kerley, G.I., 2009. Fencing for conservation: Restriction of evolutionary potential or a riposte to threatening processes? Biological Conservation 142, 1-13.

38. James, A.I., Eldridge, D.J., 2007. Reintroduction of fossorial native mammals and potential impacts on ecosystem processes in an Australian desert landscape. Biological Conservation 138, 351-359.

39. James, A.I., Eldridge, D.J., Hill, B.M., 2009. Foraging animals create fertile patches in an Australian desert shrubland. Ecography 32, 723-732.

40. James, C.D., Landsberg, J., Morton, S.R., 1995. Ecological functioning in arid Australia and research to assist conservation of biodiversity. Pacific Conservation Biology 2, 126-142. 
41. Jones, C., Lawton, J., Shachak, M., 1996. Organisms as Ecosystem Engineers, Ecosystem Management. Springer New York, pp. 130-147.

42. Jones, D., Susilo, F., Bignell, D., Hardiwinoto, S., Gillison, A., Eggleton, P., 2003. Termite assemblage collapse along a land-use intensification gradient in lowland central Sumatra, Indonesia. Journal of Applied Ecology 40, 380-391.

43. Lenz, M., Kard, B., Evans, T.A., Mauldin, J.K., Etheridge, J.L., Abbey, H.M., 2009. Differential use of identical food resources by Reticulitermes flavipes (Isoptera: Rhinotermitidae) in two types of habitats. Environmental Entomology 38, 35-42.

44. Lima, S.L., 1998. Nonlethal effects in the ecology of predator-prey intreractions. BioScience 48, 25-34.

45. Lima, S.L., Dill, L.M., 1990. Behavioral decisions made under the risk of predation: a review and prospectus. Canadian Journal of Zoology 68, 619-640.

46. Manning, A.D., Eldridge, D.J., Jones, C.G., 2015. Policy implications of ecosystem engineering for multiple ecosystem benefits, in: Armstrong, D., Hayward, M., Moro, D., Seddon, P. (Eds.), Advances in Reintroduction Biology of Australian and New Zealand Fauna. CSIRO Publishing, Australia.

47. Matthews, E.G., 1976. Insect ecology. University of Queensland Press, St. Lucia, Queensland, Australia.

48. McAfee, D., Cole, V.J., Bishop, M.J., 2015. Latitudinal gradients in ecosystem engineering by oysters vary across habitats. Ecology.

49. McDonnell, M.J., Pickett, S.T.A., Groffman, P., Bohlen, P., Pouyat, R.V., Zipperer, W.C., Parmelee, R.W., Carreiro, M.M., Medley, K., 1997. Ecosystem processes along an urban-to-rural gradient. Urban Ecosystems 1, 21-36.

50. McKenzie, N., Burbidge, A., Baynes, A., Brereton, R., Dickman, C., Gordon, G., Gibson, L., Menkhorst, P., Robinson, A., Williams, M., 2007. Analysis of factors implicated in the recent decline of Australia's mammal fauna. Journal of Biogeography 34, 597-611.

51. Mora, P., Miambi, E., Jiménez, J., Decaëns, T., Rouland, C., 2005. Functional complement of biogenic structures produced by earthworms, termites and ants in the neotropical savannas. Soil Biology and Biochemistry 37, 1043-1048.

52. Morton, S., Smith, D.S., Dickman, C., Dunkerley, D., Friedel, M., McAllister, R., Reid, J., Roshier, D., Smith, M., Walsh, F., 2011. A fresh framework for the ecology of arid Australia. Journal of Arid Environments 75, 313-329.

53. Morton, S.R., James, C.D., 1988. The diversity and abundance of lizards in arid Australia: a new hypothesis. American Naturalist, 237-256.

54. Moseby, K.E., \#39, Donnell, E., 2003. Reintroduction of the greater bilby, $<\mathrm{i}>$ Macrotis $</ \mathrm{i}>$ $<$ i>lagotis $<$ /i $>$ (Reid) (Marsupialia : Thylacomyidae), to northern South Australia: survival, ecology and notes on reintroduction protocols. Wildlife Research 30, 15-27.

55. Navnith, M., Finlayson, G., Crowther, M., Dickman, C., 2009. The diet of the re-introduced greater bilby Macrotis lagotis in the mallee woodlands of western New South Wales. Australian Zoologist 35, 90-95.

56. Nogués-Bravo, D., Simberloff, D., Rahbek, C., Sanders, N.J., 2016. Rewilding is the new Pandora's box in conservation. Current Biology 26, R87-R91.

57. Oksanen, L., Fretwell, S.D., Arruda, J., Niemela, P., 1981. Exploitation ecosystems in gradients of primary productivity. American Naturalist, 240-261.

58. Pavey, C., 2006. National Recovery Plan for the Greater Bilby. Macrotis lagotis.

59. R Core Team, 2015. R: A Language and Environment for Statistical Computing. R Foundation for Statistical Computing, Vienna, Austria.

60. Read, J., Carter, J., Moseby, K., Greenville, A., 2008. Ecological roles of rabbit, bettong and bilby warrens in arid Australia. Journal of Arid Environments 72, 2124-2130. 
61. Reynolds, J.F., Smith, D.M., Lambin, E.F., Turner, B.L., Mortimore, M., 2007. Global desertification: building a science for dryland development. Science 316, 847-851.

62. Robley, A.J., Short, J., Bradley, S., 2001. Dietary overlap between the burrowing bettong (Bettongia lesueur) and the European rabbit (Oryctolagus cuniculus) in semi-arid coastal Western Australia. Wildlife Research 28, 341-349.

63. Rodríguez-Castañeda, G., 2013. The world and its shades of green: a meta-analysis on trophic cascades across temperature and precipitation gradients. Global Ecology and Biogeography 22, 118-130.

64. Romero, G.Q., Gonçalves-Souza, T., Vieira, C., Koricheva, J., 2015. Ecosystem engineering effects on species diversity across ecosystems: a meta-analysis. Biological Reviews 90, 877-890.

65. Sheppe, W., 1970. Invertebrate predation on termites of the African Savanna. Insectes Sociaux $17,205-218$.

66. Short, J., Turner, B., 2000. Reintroduction of the burrowing bettong Bettongia lesueur (Marsupialia: Potoroidae) to mainland Australia. Biological Conservation 96, 185-196.

67. Silvey, C.J., Hayward, M.W., Gibb, H., 2015. Effects of reconstruction of a pre-European vertebrate assemblage on ground-dwelling arachnids in arid Australia. Oecologia 178, 497-509.

68. Southgate, R., Carthew, S.M., 2006. Diet of the bilby (Macrotis lagotis) in relation to substrate, fire and rainfall characteristics in the Tanami Desert. Wildlife Research 33, 507-519.

69. Tabari, H., Aghajanloo, M.-B., 2013. Temporal pattern of aridity index in Iran with considering precipitation and evapotranspiration trends. International Journal of Climatology 33, 396-409.

70. Travers, S.K., 2013. Aspects of litter dynamics in semi-arid environments in eastern Australia, Science. The University of New South Wales, Australia, p. 251.

71. Vieira, E.M., Finlayson, G.R., Dickman, C.R., 2007. Habitat use and density of numbats (Myrmecobius fasciatus) reintroduced in an area of mallee vegetation, New South Wales. Australian Mammalogy 29, 17-24.

72. Watson, J.A.L., Abbey, H.M., 1993. Atlas of Australian termites. CSIRO PUBLISHING.

73. Whitford, W.G., Kay, F.R., 1999. Biopedturbation by mammals in deserts: a review. Journal of Arid Environments 41, 203-230.

74. Woinarski, J.C., Burbidge, A.A., Harrison, P.L., 2015. Ongoing unraveling of a continental fauna: Decline and extinction of Australian mammals since European settlement. Proceedings of the National Academy of Sciences 112, 4531-4540. 